Nakon što je Donald Trump u studenome ove godine „neočekivano“ postao novi američki predsjednik, američki mainstream mediji našli su se na udaru kritika medijskih stručnjaka i politologa, ali i građana, kako iz SAD-a tako i iz ostalih dijelova svijeta. Postavljeno je pitanje kako je moguće da su istraživanja javnog mnijenja i medijske analize toliko pogriješili. Prateći predizbornu kampanju za američke predsjedničke izbore 2016. godine, kao i reakcije u medijima objavljene odmah poslije izbora, uvjerili smo se iznova koliko je važno znanstveno pristupati istraživanju političke komunikacije. Riječ je o interdisciplinarnom području koje uključuje politologe, komunikologe i medijske stručnjake, a često u istraživanjima sudjeluju i lingvisti, sociolozi i pravnici.

„Komunikacija, demokracija i digitalna tehnologija“ (Communication, Democracy and Digital Technology) bila je tema konferencije koja se u listopadu 2015. održala u Rovinju u organizaciji IPSA-e (International Political Science Association), u suradnji s Fakultetom političkih znanosti Sveučilišta u Zagrebu. Tada je dogovoren i ovaj tematski broj časopisa istoga naslova. Interes autorica i autora za objavu članaka u ovom tematskom broju bio je veliki pa zadatak gostujućih urednica i urednika u selekciji radova nije bio nimalo lak. Ponajprije želim zahvaliti Marijani Grbeša s Fakulteta političkih znanosti Sveučilišta u Zagrebu i Darrenu Lillakeru sa Sveučilišta Bournemouth iz Dorseta u Ujedinjenom Kraljevstvu na predanom radu pri uređivanju ovog tematskog broja.

U ovom tematskom broju, poslije uvodnog članka gostujućih urednika, donosimo devet članaka koji su podijeljeni u tri poglavlja: E-demokracija, Javna deliberacija te Društveni mediji i politički diskurs. Članci autorica i autora iz Italije, Španjolske, Ujedinjenog Kraljevstva te iz Brazila obrađuju teme koje se odnose na modele kojima vlade i javne administracije mogu poduprijeti građansku participaciju koristeći digitalne komunikacijske platforme. Riječ je o modelima kao što su e-vlada, otvorena vlada te specifično dizajnirani modeli digitalne demokracije. O javnoj deliberaciji pišu autorice i autori iz Grčke i Španjolske, naglašavajući koliko su pristup informacijama kroz deliberativne procedure te mogućnost stjecanja znanja o javnim politikama važni za formiranje mišljenja građana o pojedinim temama. U trećem poglavlju autorice i autori iz Španjolske, Finske i Češke donose rezultate svojih istraživanja o tome kako političke stranke, političari i građani koriste društvene mreže, prije svega Twitter i Facebook, za promidžbu svojih ciljeva i ideja, odnosno za pozivanje na javnu reakciju.

Na kraju ne smijemo ignorirati činjenicu da je Ministarstvo znanosti i obrazovanja Republike Hrvatske odluku o financiranju znanstvenih časopisa u 2016. godini donijelo tek 14. prosinca 2016. U uvjetima bez stabilnog izvora pa makar i minimalnih sredstava za opstanak časopisa sve što činimo da Medijske studije zadrže postignutu razinu kvalitete selekcije i uređivanja članaka ne možemo nazvati drugim imenom do "gerilskog" stila samoodrživosti.

\title{
Viktorija Car
}

glavna urednica 